\title{
EFEKT SKALI I EFEKT SELEKCJ I PO PRZYSTĄPIENIU POLSKI DO UNII EUROPEJSKIEJ
}

\section{WSTĘP}

Okres ostatnich siedmiu lat to czas istotnych zmian, jakie zaszły w gospodarce naszego kraju w wyniku wstąpienia do Unii Europejskiej. Wiele opublikowanych dotychczas raportów i analiz przedstawia różne oceny zarówno w kontekście mikro-, jak i makroekonomicznym. Wejście w życie porozumień integracyjnych stworzyło nowe warunki dla wszystkich podmiotów gospodarczych działających $\mathrm{w}$ integrujących się gospodarkach.

Jeszcze przed 1 maja 2004 r. wielu ekonomistów próbowało przewidzieć wyniki rozszerzenia UE. Dziś jest to łatwiejsze, a dane pomagają także ocenić, czy publikowane wówczas sądy i przewidywania były trafne.

W niniejszej pracy zostanie wykorzystany model Krugmana dotyczący efektu skali i selekcji po otwarciu gospodarki danego kraju. Niniejsze opracowanie będzie poświęcone Polsce i wybranym branżom produkcyjnym. Na podstawie danych o działalności polskich przedsiębiorstw zostanie przedstawiona empiryczna weryfikacja modelu Krugmana i dzięki temu zostanie dokonana ocena wpływu otwarcia gospodarki na funkcjonowanie przedsiębiorstw produkcyjnych.

W badaniu wykorzystano dane o produkcji w głównych branżach przemysłowych na podstawie podziału stosowanego przez Główny Urząd Statystyczny i publikowanego w roczniku „Nakłady i wyniki przemysłu”.

\section{EFEKT SKALI A EFEKT SELEKCJI W MODELU KRUGMANA}

Okres ostatnich siedmiu lat przyniósł znaczące zmiany w polskiej gospodarce. Po przystąpieniu do Unii Europejskiej w maju 2004 r. obserwowano w Polsce dynamicznie zmieniające się warunki gospodarcze, szczególnie z punktu widzenia mi- 
kroekonomicznego. Polskie przedsiębiorstwa uzyskały co prawda w ramach unii gospodarczej nieograniczony barierami handlowymi dostęp do wielu rynków, ale stanęły wobec napływającego na rynek polski wielkiego strumienia dóbr pochodzących od konkurentów z innych krajów UE. Należy zaznaczyć, iż Polska była z krajami UE-15 w strefie wolnego handlu dużo wcześniej, niż nastąpiło rozszerzenie Unii w 2004 r. Tę datę uznano jednak za kluczową, jeśli chodzi o otwarcie gospodarki nie tylko na rynku całej Unii (poza Polską w 2004 r. uczestniczyły w niej 24 kraje, w 2011 r. 27 kraje), ale także na rynkach krajów będących w strefie wolnego handlu $z$ UE.

Otwarcie gospodarki to przede wszystkim korzyści wynikające ze wzrostu produkcji, rozszerzenia rynków zbytu. Korzyści konsumentów z kolei to dostęp do bardziej zróżnicowanej oferty.

$\mathrm{Z}$ modelu wynika jednak także inny ważny wniosek - im więcej producentów jest na rynku, tym wyższy jest koszt przeciętny ich działalności (jeśli rośnie n, rośnie AC), oraz w miarę wzrostu liczby producentów na rynku spada cena oferowanych przez nich dóbr (jeśli rośnie n, spada $\mathrm{P}$ ) (zob. rysunek 1). Równowaga na rynku występuje w punkcie przecięcia krzywej CC i PP. Jest to punkt, w którym cena ma wartość kosztu przeciętnego, czyli nie występuje zysk.

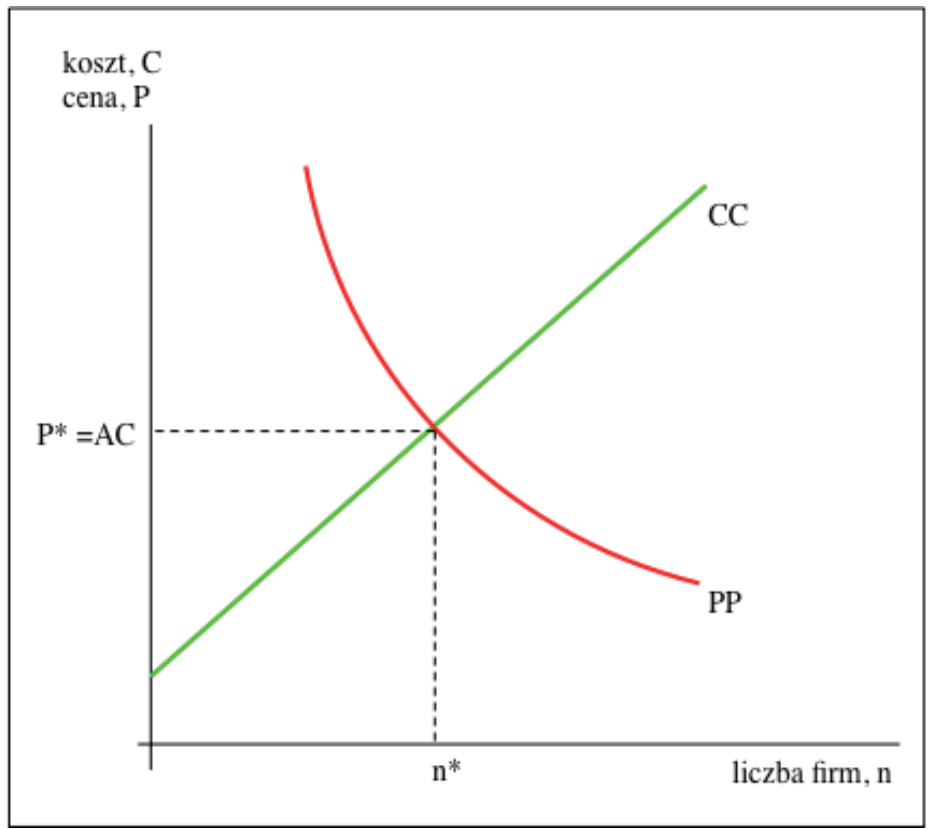

Rysunek 1. Model Krugmana w gospodarce zamkniętej

Źródło: na podstawie R. Feenstra, Advanced International Trade: Theory and Evidence, Princeton University Press 2003. 
Koszt stały wyznacza rosnącą krzywą podaży branży (CC) - im więcej firm, tym większy koszt. Większa liczba producentów na rynku oznacza konieczność ponoszenia przez nich wyższych kosztów przeciętnych.

Konkurencja monopolistyczna wyznacza opadającą krzywą popytu branży (PP). Jeśli $\mathrm{w}$ branży działa $\mathrm{n}_{1}\left(\mathrm{n}_{1}<\mathrm{n}^{*}\right)$ firm, każda $\mathrm{z}$ nich osiąga zysk $-\mathrm{w}$ branży pojawiają się nowi producenci $(\mathrm{CC}<\mathrm{PP})$. Jeśli w branży działa $\mathrm{n}_{2}\left(\mathrm{n}_{2}>\mathrm{n}^{*}\right)$ firm, każda $z$ nich osiąga stratę - firmy wychodzą z branży $(\mathrm{CC}>\mathrm{PP})$. Tylko przy liczbie $\mathrm{n}^{*}$ firm w branży każda $\mathrm{z}$ firm osiąga 0 zysk - brak firm wchodzących/wychodzących.

Teraz przeanalizujmy krzywą popytu branży (PP) i krzywą podaży branży (CC) w odniesieniu do gospodarki otwartej.

W wyniku otwarcia gospodarki krzywa CC ulega przesunięciu do $\mathrm{CC}_{1}$. Oznacza to wzrost liczby firm na rynku. Producenci zagraniczni oferują produkty na nowym rynku, a krajowi mogą zwiększyć produkcję dzięki dostępowi do rynku zagranicznego.

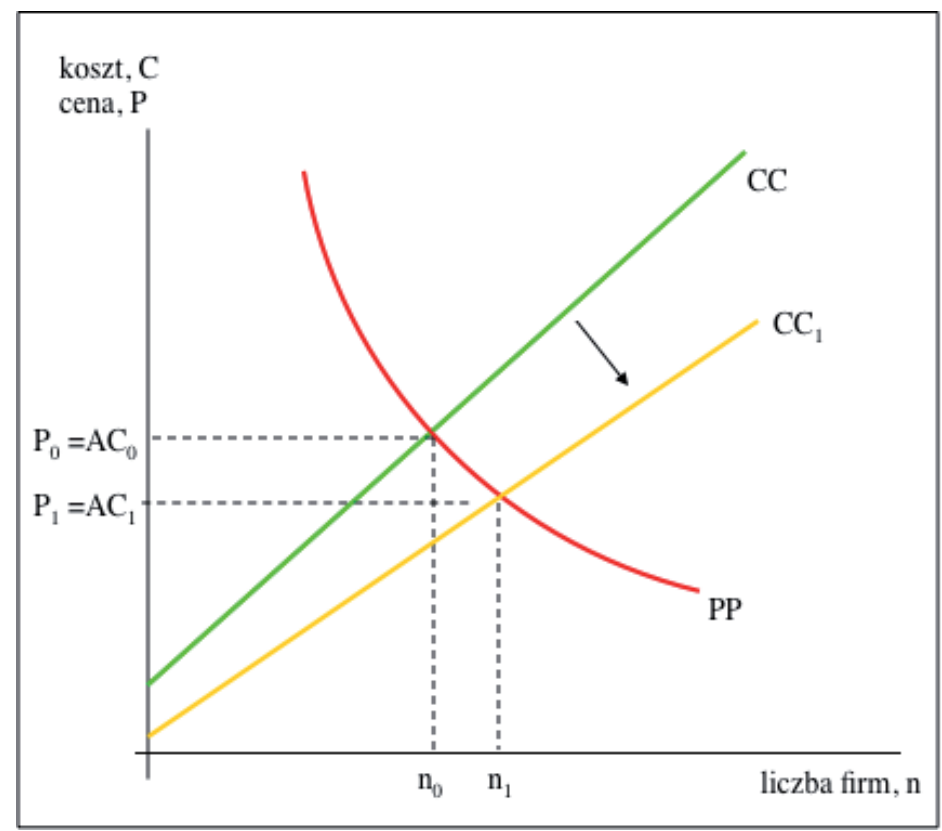

Rysunek 2. Model Krugmana w gospodarce otwartej

Źródło: na podstawie R. Feenstra, Advanced International Trade: Theory and Evidence, Princeton University Press 2003.

W wyniku wzrostu ilości produktów następuje spadek ceny $\left(z \mathrm{P}_{0}\right.$ do $\left.\mathrm{P}_{1}\right)$. Ponadto, warto zauważyć, że dzięki występowaniu rosnących korzyści skali oraz 
potrzebom konsumentów związanym $\mathrm{z}$ różnorodnością dóbr korzyści z handlu mogą odnosić nawet kraje o identycznych gospodarkach i strukturze produkcji, bo handel dotyczy dóbr zróżnicowanych. Kierunków handlu nie wyznaczają więc - jak w teoriach klasycznych - przewagi absolutne lub komparatywne.

Powstaje jednak pytanie, czy otwarcie gospodarki we wszystkich przypadkach spowoduje wzrost produkcji krajowej. Odpowiedź znajdziemy, posługując się formułą obrazującą nakład pracy potrzebny do produkcji dobra $i$ oraz funkcją kosztu całkowitego tej produkcji. Zakładamy, że do produkcji dobra $i$ wykorzystuje się tylko jeden czynnik produkcji - pracę $(L)$. Przyjmując za $N$ liczbę producentów, możemy sformułować warunek pełnego zatrudnienia zasobów czynnika produkcji (pracy) na rynku.

$$
\begin{aligned}
& L=\sum_{i=1}^{N} L_{i}=\sum_{i=1}^{N}\left(\alpha+\beta \cdot y_{i}\right)=N(\alpha+\beta \cdot y) \\
& N=\frac{1}{\frac{\alpha}{L}+\beta \cdot c},
\end{aligned}
$$

z czego:

$$
L=N(\alpha+\beta \cdot y)
$$

$\mathrm{L}_{\mathrm{i}}-$ nakład pracy w produkcji dobra $i$

$\mathrm{y}_{\mathrm{i}}$ - produkcja dobra $i$

$\alpha$ - stały nakład do rozpoczęcia produkcji

$\beta$ - krańcowy produkt pracy

$\mathrm{w}$ - koszt jednostki pracy $\mathrm{L}$

Na podstawie powyższego równania możemy zauważyć, że jeśli zasoby czynnika produkcji nie zmieniają się ( $L$ jest wartością stałą) i występują rosnące korzyści skali, wtedy przy wzroście produkcji danego dobra $(y)$ spadnie liczba firm $(N)$. W rzeczywistości otwarcie gospodarki powoduje wzrost produkcji w firmach, które funkcjonują na poszerzonym rynku. Wiąże się to jednak ze spadkiem liczby firm, które nie zdołają stawić czoła napływającym z zagranicy dobrom konkurencyjnym.

Podsumowując, możemy stwierdzić, że w wyniku otwarcia gospodarki mamy do czynienia $z$ dwoma przeciwnymi efektami - efektem skali, kiedy firmy zwiększają produkcję, oraz efektem selekcji, gdy firmy pod presją konkurencji zmuszone są wyjść $z$ branży. 
Po raz pierwszy badania empiryczne tych efektów przeprowadzili K. Head, J. Ries (1999). Przeanalizowali oni dane o produkcji i wydajności 230 kanadyjskich firm w latach 1988-1994. Badanie miało na celu określenie wpływu strefy wolnego handlu pomiędzy Stanami Zjednoczonymi i Kanadą na produkcję kanadyjską. Wyniki badań pozwoliły przedstawić dwa interesujące wnioski. Po pierwsze, w efekcie wprowadzenia strefy wolnego handlu pomiędzy wymienionymi krajami w Kanadzie nastąpił wzrost produkcji o 10\%. Wynik ten dotyczył głównie firm eksportujących do Stanów Zjednoczonych. Biorąc pod uwagę dotychczas przedstawiony model Krugmana, możemy wnioskować, iz jest to empirycznie udowodniony efekt skali. Po drugie, w przedsiębiorstwach kanadyjskich zaobserwowano spadek produkcji o 8,5\%. Wynik ten dotyczył przede wszystkim firm konkurujących z importem ze Stanów Zjednoczonych. Jest to niewątpliwie dowód na wystąpienie efektu selekcji.

Wykorzystując przedstawiony model Krugmana, spróbujmy zastanowić się i przeanalizować zmiany skali działalności polskich przedsiębiorstw po wejściu Polski do Unii Europejskiej.

\section{ROSNĄCE KORZYŚCI SKALI. EFEKT SKALI}

Po ponad siedmiu latach doświadczeń wynikających z członkostwa Polski w UE można już dokonać oceny skutków przystąpienia naszego kraju do UE. Chociaż jeszcze przed 2004 r. mieliśmy całkowicie otwarte rynki starej Unii dla towarów z Polski, to data akcesji Polski do UE w 2004 r. stanowi realną pełną integrację gospodarczą Polski z Unią Europejską i przyjęcie przez Polskę unijnej polityki handlowej. W przedstawionych badaniach podjęta zostanie próba oceny efektu otwarcia rynku polskiego. Skutki integracji gospodarczej ocenione będą na podstawie bilansu dwóch efektów - skali i selekcji. Podobnie jak w dotychczas przeprowadzonych wielu badaniach wykorzystujących modele Krugmana, podjęta będzie próba odpowiedzi na pytanie, czy w wyniku otwarcia rynku gospodarka odniosła korzyści (efekt skali lub efekt selekcji skutkujący wzrostem wydajności), czy straty (efekt selekcji) wynikające ze spadku produkcji związanej z obniżeniem liczby firm krajowych. 


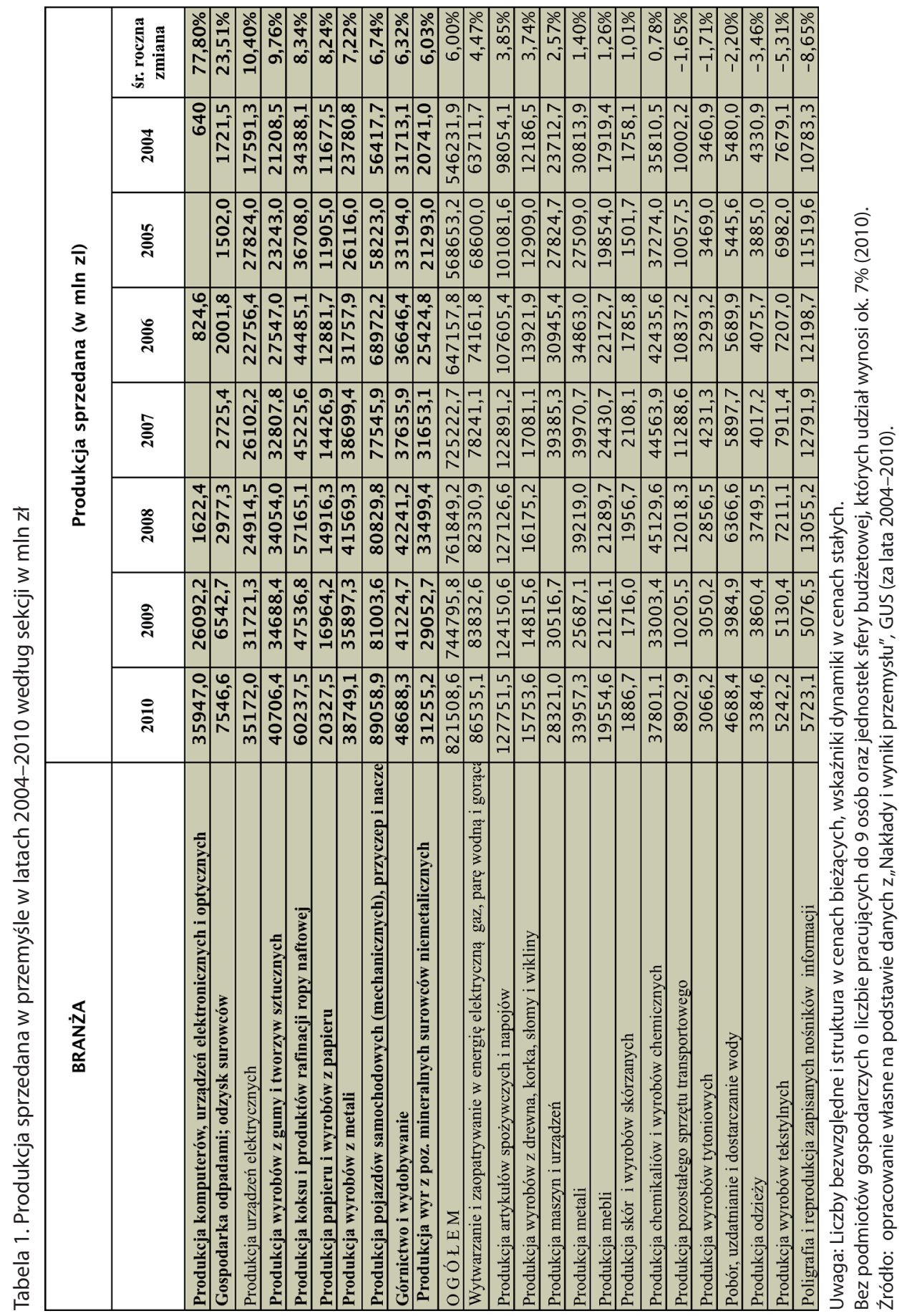


Na podstawie danych przedstawionych w tabeli 1 zauważamy, że największą zmianę wartości sprzedaży w latach 2004-2010 zanotowano w sektorze produkcji komputerów, wyrobów elektronicznych i optycznych. Sprzedaż w tej branży wzrastała średniorocznie o ponad 77\%. W analizowanym okresie zwiększyła się bowiem z $640 \mathrm{mln}$ zł rocznie do ponad $35 \mathrm{mld}$ zł.

W większości branż w latach 2008-2009 nastąpił nieznaczny spadek corocznych wzrostów i 2009 r. był raczej gorszy pod względem sprzedaży od roku poprzedniego. Niemniej poza jednym rokiem zmniejszenia wartości sprzedaży oraz spadkiem, który nastąpił w produkcji urządzeń elektrycznych w latach 2005-2006 (o 19\%), wszystkie przedstawione branże notowały coroczne wzrosty wartości sprzedaży. Warto zauważyć, iż wiele spośród dóbr produkowanych w opisywanych branżach to dobra, które zajmują ważne miejsce w strukturze polskiego eksportu. Samochody osobowe i ciężarowe w całości eksportu to aż 16,5\% polskiego eksportu i 11,1\% importu.

Można wnioskować, że wzrost sprzedaży w tym sektorze to wyraźny efekt skali osiągnięty po otwarciu rynków. Polscy producenci samochodów i części nie znaleźliby na krajowym rynku wystarczającego zbytu dla własnej produkcji. Dzięki otwarciu rynków mają możliwość sprzedaży za granicą. Aktywność zagraniczną widać wyraźnie w wynikach sprzedaży, które w ostatnim czasie wyraźnie się poprawiają. Według szacunków Eurostat do końca 2011 r. wartość eksportu aut i części z polskich fabryk sięgnie 19 mld euro (81,7 mld z1). W maju br. wartość polskiej produkcji samochodów oraz części sprzedanych za granicę wyniosła 1,73 mld euro. W porównaniu z tym samym okresem roku poprzedniego nastąpił wzrost o $17 \%$. W tej branży najważniejsze miejsce zajmują samochody osobowe i dostawcze oraz części i akcesoria.

Jeśli chodzi o zagraniczną sprzedaż części i akcesoriów, w pierwszym półroczu 2011 r. wzrosła o 17,5\% w porównaniu z pierwszym półroczem roku poprzedniego. Największym odbiorcą produkowanych w Polsce części są Niemcy, gdzie fabryki wykorzystują polskie podzespoły do własnej produkcji.

Porównanie wyników sprzedaży zagranicznej z 2004 r. i 2010 r. przedstawia tabela 2. Jak wykazano, pojazdy samochodowe nie znajdują się na czele listy branż, których sprzedaż eksportowa wzrosła najbardziej. W tej branży sprzedaż zagraniczna w 2010 r. w stosunku do 2004 r. wzrosła o prawie 54,64\%. Liderem listy są chemikalia i wyroby chemiczne, które zanotowały wzrost sprzedaży zagranicznej w opisywanym okresie o 109,3\%. Podobny wzrost sprzedaży nastąpił w branży spożywczej.

Jak szacuje Instytut Ekonomiki Rolnictwa i Gospodarki Żywnościowej, wartość eksportu produktów rolno-spożywczych w 2011 r. wzrośnie o 6\% wobec 2010 r. i wyniesie około 14,1 mld euro. Wydatki na import wzrosną o około $10 \%$ - do 11,8 mld euro. Ujemne saldo obrotów zmniejszy się z 2,6 mld euro 
w 2010 r. do 2,3 mld euro w 2011 r. Zdaniem przedstawicieli Instytutu spodziewana koniunkturalna poprawa sytuacji gospodarczej u naszych głównych partnerów handlowych w krajach Unii Europejskiej będzie miała decydujący wpływ na rozwój sytuacji w polskim handlu zagranicznym w 2011 r. Chociaż utrzymujące się wysokie ceny zbóż i innych surowców paszowych spowodują spadek dynamiki wzrostu produkcji zwierzęcej w Polsce, to szacunki Instytutu wskazują, że wpływ zewnętrznych czynników, tj. rosnący popyt, spowoduje, że obroty handlu zagranicznego pozostaną w trendzie wzrostowym.

Tabela 2. Przychody ze sprzedaży zagranicznej w latach 2004 i 2010 w mln zł

\begin{tabular}{|c|c|c|c|}
\hline \multirow[t]{2}{*}{ BRANŻA } & \multicolumn{2}{|c|}{$\begin{array}{l}\text { przychody ze sprzedaży } \\
\text { zagranicznej (w mln zl) }\end{array}$} & \multirow{2}{*}{$\begin{array}{c}\text { zmiana } \\
2010 / 2004 \text { (w } \\
\text { proc.) }\end{array}$} \\
\hline & 2004 & 2010 & \\
\hline Produkcja urządzeń elektrycznych & 31672 & 96228 & $203,83 \%$ \\
\hline Produkcja wyrobów tytoniowych & 1788 & 4748 & $165,47 \%$ \\
\hline Produkcja chemikaliów i wyrobów chemicznych & 15021 & 31440 & $109,30 \%$ \\
\hline Produkcja artykułów spożywczych i napojów & 12037 & 24854 & $106,49 \%$ \\
\hline Produkcja wyrobów z gumy i tworzyw sztucznych & 16079 & 31412 & $95,36 \%$ \\
\hline Produkcja maszyn i urządzeń & 65323 & 125373 & $91,93 \%$ \\
\hline Pordukcja koksu i produktów rafinacji ropy naftowej & 7793 & 13531 & $73,64 \%$ \\
\hline Produkcja komputerów, wyrobów elektronicznych i optycznych & 2744 & 4564 & $66,32 \%$ \\
\hline Produkcja papieru i wyrobów z papieru & 9053 & 14999 & $65,67 \%$ \\
\hline Produkcja wyrobów z metali & 35790 & 55682 & $55,58 \%$ \\
\hline O GÓŁEM & 461125 & 714268 & $54,90 \%$ \\
\hline Produkcja poj azdów samochodowych (mechanicznych), przyczep i naczep & 49107 & 75940 & $54,64 \%$ \\
\hline Produkcja metali & 34538 & 50891 & $47,35 \%$ \\
\hline Produkcja mebli & 20734 & 26911 & $29,79 \%$ \\
\hline Produkcja wyrobów tekstylnych & 12253 & 15814 & $29,06 \%$ \\
\hline Produkcja wyrobów z pozostałych mineralnych surowców niemetalicznych & 16032 & 20595 & $28,46 \%$ \\
\hline Produkcja wyrobów z drewna, korka, stomy i wikliny & 8355 & 9999 & $19,68 \%$ \\
\hline Produkcja skór i wyrobów skórzanych & 2081 & 1938 & $-6,84 \%$ \\
\hline Wytwarzanie i zaopatrywanie w energię elektryczną gaz, parę wodną i gorącą wodę & 2060 & 1617 & $-21,51 \%$ \\
\hline Górnictwo i wydobywanie & 5774 & 4193 & $-27,39 \%$ \\
\hline Produkcja odzieży & 12891 & 3540 & $-72,54 \%$ \\
\hline Poligrafia i reprodukcja zapisanych nośników informacji & b.d. & b.d. & \\
\hline Produkcja pozostałego sprzętu transportowego & b.d. & b.d. & \\
\hline Pobór, uzdatnianie i dostarczanie wody & b.d. & b.d. & \\
\hline Gospodarka odpadami; odzysk surowców & b.d. & 4769 & \\
\hline
\end{tabular}

Uwaga: Liczby bezwzględne i struktura w cenach bieżących, wskaźniki dynamiki w cenach stałych.

Bez podmiotów gospodarczych o liczbie pracujących do 9 osób oraz jednostek sfery budżetowej, których udział wynosi ok. 7\% (2010).

Źródło: opracowanie własne na podstawie danych z Handel zagraniczny (styczeń-grudzień), GUS, za lata $2004,2010^{1}$.

$Z$ danych w tabeli 2 widać także, że znaczący spadek sprzedaży eksportowej w analizowanym okresie zanotowały takie dobra, jak skóry i wyroby skórzane, energia elektryczna, produkty górnicze oraz odzież. Branża odzieżowa w Polsce

1 W celu zachowania jednorodności danych w dalszej analizie poszczególnym branżom przyporządkowano grupy towarowe według sekcji CN. 
jest bez wątpienia najbardziej dotknięta przez konkurencję zagraniczną. Zmaga się bowiem nie tylko z konkurencją produkcji z Chin i innych krajów azjatyckich. Polskim producentom odzieży nie sprzyjają także silni konkurenci z Unii Europejskiej. UE to nadal największy światowy eksporter wyrobów włókienniczych (33,7\% światowego eksportu) i drugi po Chinach eksporter odzieży $(26,8 \%$ światowego eksportu). W krajach członkowskich UE w branży włókienniczej i odzieżowej działa prawie 181 tys. producentów (dane z 2010 r.). W stosunku do roku poprzedniego liczba zatrudnionych $\mathrm{w}$ tej branży spadła o prawie $6,5 \%{ }^{2}$. Obserwowanemu w UE spadkowi zatrudnienia w branży odzieżowej - średnio o 3\% rocznie w ciągu ostatnich 10 lat - towarzyszy wzrost wydajności pracy, który w ostatnich latach (2008-2010) wynosił około $2 \%$ rocznie.

Tabela 3. Liczba przedsiębiorstw w wybranych branżach w latach 2004 i 2010

\begin{tabular}{|c|c|c|c|}
\hline \multirow[t]{2}{*}{ BRANŻA } & \multicolumn{3}{|c|}{ liczba przedsiębiorstw } \\
\hline & 2004 & 2010 & $\begin{array}{c}\text { zmiana } \\
\text { 2010/2004 (w } \\
\text { proc.) }\end{array}$ \\
\hline Produkcja komputerów, urządzeń elektronicznych i optycznych & 15 & 153 & $920,00 \%$ \\
\hline Gospodarka odpadami; odzysk surowców & 30 & 230 & $666,67 \%$ \\
\hline Produkcja poj azdów samochodowych (mechanicznych), przyczep i naczep & 226 & 290 & $28,32 \%$ \\
\hline Produkcja wyrobów z gumy i tworzyw sztucznych & 481 & 609 & $26,61 \%$ \\
\hline Produkcja papieru i wyrobów z papieru & 169 & 209 & $23,67 \%$ \\
\hline Produkcja wyrobów z metali & 777 & 959 & $23,42 \%$ \\
\hline Produkcja wyrobów tytoniowych & 10 & 12 & $20,00 \%$ \\
\hline Produkcja koksu i produktów rafinacji ropy naftowej & 22 & 25 & $13,64 \%$ \\
\hline OGÓŁEM & 8014 & 8174 & $2,00 \%$ \\
\hline Produkcja metali & 157 & 158 & $0,64 \%$ \\
\hline Produkcja wyrobów z drewna, korka, słomy i wikliny & 342 & 338 & $-1,17 \%$ \\
\hline Produkcja wyr z poz. mineralnych surowców niemetalicznych & 406 & 395 & $-2,71 \%$ \\
\hline Produkcja urządzeń elektrycznych & 275 & 264 & $-4,00 \%$ \\
\hline Produkcja artykułów spożywczych i napojów & 1476 & 1365 & $-7,52 \%$ \\
\hline Produkcja mebli & 506 & 429 & $-15,22 \%$ \\
\hline Produkcja pozostałego sprzętu transportowego & 122 & 98 & $-19,67 \%$ \\
\hline Produkcja maszyn i urządzeń & 682 & 545 & $-20,09 \%$ \\
\hline Produkcja chemikaliów i wyrobów chemicznych & 274 & 213 & $-22,26 \%$ \\
\hline Wytwarzanie i zaopatrywanie w energię elektryczną gaz, parę wodną i gorącą wodę & 342 & 258 & $-24,56 \%$ \\
\hline Produkcja skór i wyrobów skórzanych & 130 & 93 & $-28,46 \%$ \\
\hline Pobór, uzdatnianie i dostarczanie wody & 230 & 153 & $-33,48 \%$ \\
\hline Produkcja odzieży & 496 & 327 & $-34,07 \%$ \\
\hline Górnictwo i wydobywanie & 29 & 19 & $-34,48 \%$ \\
\hline Produkcja wyrobów tekstylnych & 295 & 180 & $-38,98 \%$ \\
\hline Poligrafia i reprodukcja zapisanych nośników informacji & 235 & 119 & $-49,36 \%$ \\
\hline
\end{tabular}

Źródło: opracowanie własne na podstawie danych z "Nakłady i wyniki przemysłu”, GUS (za lata 2004, 2010).

Wobec omówionych wyników sprzedaży polskich przedsiębiorstw produkcyjnych nie zaskakują dane o zmieniającej się ich liczbie. W prawie wszystkich branżach, których sprzedaż wzrosła szybciej niż sprzedaż produkcji przemysłowej ogółem - czyli ponad 6\%, nastąpił w latach 2004-2010 wzrost liczby producen-

\footnotetext{
2 Dane Europejskiej Organizacji Odzieżowo-Włókienniczej (Euratex).
} 
tów. Przy czym największa zmiana nastąpiła w branży komputerowej, gdzie liczba przedsiębiorstw wzrosła z 15 do 153. Wartość sprzedaży w tej branży w $2004 \mathrm{r}$. była niewielka i wyniosła $640 \mathrm{mln}$ zł, a w 2010 r. sprzedaż wzrosła do prawie 36 mld zł. Gospodarka odpadami to druga z branż w czołówce listy przedstawiającej zmiany liczby przedsiębiorstw w latach 2004-2010. Trudno jednak ocenić związki producentów z tej branży z rynkami zagranicznymi. Zatem pomija się tu analizę efektu skali, na który oddziałują powiązania międzynarodowe. Efekt selekcji jednak może podlegać ocenie ze względu na wzrost rentowności przy jednoczesnym spadku liczby firm działających w branży.

Przedstawione dotychczas dane o działalności przedsiębiorstw produkcyjnych pozwalają na ocenę pierwszego z dwóch efektów, którym poświęcone jest niniejsze opracowanie. Na podstawie przychodów ze sprzedaży, przychodów ze sprzedaży zagranicznej oraz zmiany liczby firm w poszczególnych branżach wyznaczony zostanie efekt skali, który nastąpił $\mathrm{w}$ przedsiębiorstwach przemysłowych w Polsce w latach 2004-2010.

W tabeli 4 wykorzystano dane przedstawione w poprzednich zestawieniach i nadano im wagi, w zależności od wyniku dla całej produkcji przemysłowej. Najwyższą ocenę (++) plus-plus uzyskała branża, w której nastąpił roczny wzrost sprzedaży powyżej średniej (wynik dla całej produkcji przemysłowej). $Z$ kolei jeśli był to wynik poniżej średniej, ale przy jednoczesnym zachowaniu dodatniej średniorocznej zmiany wartości produkcji sprzedanej - oceniono branżę na (+) plus. Jeśli natomiast średniorocznie produkcja sprzedana spadała, branża uzyskała ocenę (-) minus.

Ocenę wyników przychodów ze sprzedaży zagranicznej oparto na następującej skali: w przypadku, gdy w danej branży zmiana wartości sprzedaży zagranicznej w 2010 r. w stosunku do 2004 r. wynosiła więcej niż zmiana dla całej produkcji przemysłowej - dana branża uzyskała ocenę $(++)$ plus-plus; jeśli była to zmiana poniżej wartości zmiany dla produkcji przemysłowej, ale przy utrzymaniu wartości dodatniej, czyli przychody ze sprzedaży zagranicznej w 2010 r. w porównaniu z 2004 r. wzrosły - nadano ocenę (+) plus; ocena (-) minus przypadła branżom, których przychody ze sprzedaży zagranicznej w 2010 r. spadły w porównaniu z 2004 r.

Ostatnia, trzecia kategoria wartości wpływających na efekt skali to liczba firm działających w $2010 \mathrm{r}$. w porównaniu z 2004 r. Ocenę (++) plus-plus przyznano branżom, w których w badanym okresie wzrosła liczba firm, przy czym przyrost ten musiał być większy od przyrostu liczby firm w całym przemyśle (2\%). Natomiast ocena (+) plus przypadła branży, w której zwiększyła się liczba firm, ale mniej niż średnia w przemyśle. Taką branżą jest produkcja mebli. W pozostałych branżach w latach 2004-2010 spadła liczba firm. Nadano im ocenę (-) minus. Warto przy tym zauważyć, że przy wyznaczaniu efektu skali wzięto pod uwagę wartości dodatnie tej kategorii oceny. Inaczej będzie przy ocenie efektu selekcji. 
Tabela 4. Efekt skali w Polsce w latach 2004-2010

\begin{tabular}{|c|c|c|c|c|}
\hline BRANŻA & $\begin{array}{c}\text { przychody ze } \\
\text { sprzedaży } \\
\end{array}$ & $\begin{array}{c}\text { przychody ze } \\
\text { sprzedaży } \\
\text { zagranicznej }\end{array}$ & liczba firm & $\begin{array}{l}\text { EFEKT } \\
\text { SKALI }\end{array}$ \\
\hline Górnictwo i wydobywanie & ++ & - & - & \\
\hline Produkcja artykułów spożywczych i napojów & + & ++ & - & \\
\hline Produkcja wyrobów tytoniowych & - & ++ & ++ & \\
\hline Produkcja wyrobów tekstylnych & - & + & - & \\
\hline Produkcja odzieży & - & - & - & \\
\hline Produkcja skór i wyrobów skórzanych & + & - & - & \\
\hline Produkcja wyrobów z drewna, korka, słomy i wikliny & + & + & - & \\
\hline Produkcja papieru i wyrobów z papieru & ++ & ++ & ++ & $\mathbf{x}$ \\
\hline Poligrafia i reprodukcja zapisanych nośników informacji & - & b.d. & - & \\
\hline Produkcja koksu i produktów rafinacji ropy naftowej & ++ & ++ & ++ & $\mathbf{x}$ \\
\hline Produkcja chemikaliów i wyrobów chemicznych & + & ++ & - & \\
\hline Produkcja wyrobów z gumy i tworzyw sztucznych & ++ & ++ & ++ & $\mathbf{x}$ \\
\hline Produkcja wyrobów z poz. mineralnych surowców niemetalicznych & ++ & + & - & \\
\hline Produkcja metali & + & + & + & \\
\hline Produkcja wyrobów z metali & ++ & ++ & ++ & $\mathbf{x}$ \\
\hline Produkcja komputerów, wyrobów elektronicznych i optycznych & ++ & ++ & ++ & $\mathbf{X}$ \\
\hline Produkcja urządzeń elektrycznych & ++ & ++ & - & \\
\hline Produkcja maszyn i urządzeń & + & ++ & - & \\
\hline Produkcja pojazdów samochodowych & ++ & + & ++ & $\mathbf{x}$ \\
\hline Produkcja pozostałego sprzętu transportowego & - & b.d. & - & \\
\hline Produkcja mebli & + & + & - & \\
\hline Wytwarzanie i zaopatrywanie w energię elektryczną gaz, parę & + & - & - & \\
\hline Pobór, uzdatnianie i dostarczanie wody & - & b.d. & - & \\
\hline Gospodarka odpadami; odzysk surowców & ++ & b.d. & ++ & \\
\hline
\end{tabular}

Źródło: opracowanie własne.

Powyżej przedstawiono wyniki oceny efektu skali z uwzględnieniem nadanych wag w poszczególnych kategoriach oceny. Na podstawie tych ocen możemy wyznaczyć branże, które w badanym okresie odnotowały korzyści płynące z otwarcia rynków. Wzrosły w tych branżach przychody ze sprzedaży, przychody ze sprzedaży zagranicznej oraz liczba przedsiębiorstw. Efekt skali odnotowano w produkcji papieru, produkcji koksu i produktów rafinacji ropy naftowej, produkcji wyrobów z gumy i tworzyw sztucznych, produkcji wyrobów z metali, produkcji komputerów, wyrobów elektronicznych i optycznych, a także produkcji pojazdów samochodowych.

\section{LICZBA PRZEDSIĘBIORSTW I RENTOWNOŚĆ. EFEKT SELEKCJ}

Do oceny efektu selekcji wykorzystane będą przedstawione w poprzednim rozdziale dane o zmianie liczby przedsiębiorstw w poszczególnych branżach w latach 2004-2010. Tym razem uwzględniać będziemy ocenę (-) minus, którą uzyskały branże, w których liczba przedsiębiorstw zmniejszyła się w badanym okresie. 
Drugim wskaźnikiem w tej ocenie będzie rentowność. $Z$ uwagi na brak szczegółowych danych o wydajności w poszczególnych branżach przemysłowych uznano, że rentowność obrotu brutto jako relacja wyniku finansowego brutto do przychodów z działalności jest odpowiednią miarą kondycji przedsiębiorstw i całej branży. Wskaźnik ten stanowi ocenę przedsiębiorstwa jako podmiotu osiągającego zysk lub ponoszącego stratę. Należy w tym miejscu także dodać, że z uwagi na wyniki wydajności - we wszystkich analizowanych branżach wydajność w latach 2004-2010 spadła. W związku z powyższym wskaźnika wydajności nie ujęto w kategoriach oceny efektu selekcji.

Tabela 5 przedstawia wskaźniki rentowności w analizowanych branżach przemysłowych i ich zmiany w latach 2004-2010. Najlepsze wyniki rentowności w 2010 r. uzyskały przedsiębiorstwa wytwarzające i zaopatrujące w energię elektryczną, producenci papieru i wyrobów z papieru oraz artykułów spożywczych. Nie są to jednak branże, w których nastąpiła największa poprawa rentowności działalności gospodarczej. Na czele listy branż, w których w latach 2004-2010 najbardziej poprawily się warunki gospodarowania (wzrosła rentowność), jest produkcja pozostałego sprzętu transportowego, produkcja wyrobów tytoniowych, wytwarzanie i zaopatrywanie w energię elektryczną, pobór i uzdatnianie wody oraz produkcja artykułów spożywczych.

Tabela 5. Wskaźnik rentowności obrotu brutto w latach 2004 i 2010

\begin{tabular}{|c|c|c|c|}
\hline \multirow[t]{2}{*}{ BRANŻA } & \multicolumn{3}{|c|}{$\begin{array}{l}\text { wskaźnik rentowności obrotu brutto } \\
\text { (relacja wyniku finansowego brutto } \\
\text { do przychodów z działalności) }\end{array}$} \\
\hline & 2004 & 2010 & \begin{tabular}{|c|} 
zmiana \\
$2010 / 2004$ \\
(w proc.)
\end{tabular} \\
\hline Produkcja pozostalego sprzętu transportowego & 0,7 & 2,6 & $271,43 \%$ \\
\hline Produkcja wyrobów tytoniowych & 0,8 & 2,3 & $187,50 \%$ \\
\hline Wytwarzanie i zaopatrywanie w energię elektryczną gaz, parę wodną i gorącą wodę & 5,1 & 10,9 & $113,73 \%$ \\
\hline Pobór, uzdatnianie i dostarczanie wody & 3,1 & 6,5 & $109,68 \%$ \\
\hline Produkcja artykułów spożywczych i napojów & 4,9 & 6,55 & $33,67 \%$ \\
\hline Produkcja skór i wyrobów skórzanych & 4,2 & 5,3 & $26,19 \%$ \\
\hline Gospodarka odpadami; odzysk surowców & 5,8 & 6,5 & $12,07 \%$ \\
\hline Produkcja maszyn i urządzeń & 6,1 & 6,3 & $3,28 \%$ \\
\hline Produkcja mebli & 6,5 & 6,1 & $-6,15 \%$ \\
\hline OGÓŁEM & 7,3 & 6,5 & $-10,96 \%$ \\
\hline Produkcja wyrobów tekstylnych & 5,3 & 4,5 & $-15,09 \%$ \\
\hline Produkcja odzieży & 5,6 & 4,6 & $-17,86 \%$ \\
\hline Produkcja wyrobów z gumy i tworzyw sztucznych & 7,7 & 5,9 & $-23,38 \%$ \\
\hline Produkcja urządzeń elektrycznych & 8,2 & 6,1 & $-25,61 \%$ \\
\hline Produkcja chemikaliów i wyrobów chemicznych & 8,5 & 6,3 & $-25,88 \%$ \\
\hline Produkcja wyr z poz. mineralnych surowców niemetalicznych & 11 & 8 & $-27,27 \%$ \\
\hline Produkcja wyrobów z metali & 7,9 & 5,6 & $-29,11 \%$ \\
\hline Produkcja papieru i wyrobów z papieru & 11,4 & 7,3 & $-35,96 \%$ \\
\hline Produkcja pojazdów samochodowych (mechanicznych), przyczep i naczep & 7 & 4,3 & $-38,57 \%$ \\
\hline Produkcja komputerów, urządzeń elektronicznych i optycznych & 3,8 & 2,3 & $-39,47 \%$ \\
\hline Górnictwo i wydobywanie & 14,6 & 7,2 & $-50,68 \%$ \\
\hline Poligrafia i reprodukcja zapisanych nośników informacji & 7,2 & 3,1 & $-56,94 \%$ \\
\hline Produkcja koksu i produktów rafinacji ropy naftowej & 11,9 & 4,1 & $-65,55 \%$ \\
\hline Produkcja wyrobów z drewna, korka, słomy i wikliny & 9,2 & 2,7 & $-70,65 \%$ \\
\hline Produkcja metali & 9,9 & 1 & $-89,90 \%$ \\
\hline
\end{tabular}

Źródło: opracowanie własne na podstawie danych z „Nakłady i wyniki przemysłu”, GUS (za lata 2004, 2010). 
$\mathrm{Na}$ podstawie danych o spadku liczby przedsiębiorstw w latach 2004-2010 oraz poprawie wskaźnika rentowności wybrano branże, w których wystąpił efekt selekcji przy wzroście zyskowności branży. Efekt ten dotyczył sześciu branż: produkcja artykułów spożywczych i napojów, produkcja skór i wyrobów skórzanych, produkcja maszyn i urządzeń, produkcja pozostałego sprzętu transportowego, wytwarzanie i zaopatrywanie w energię elektryczną oraz pobór, uzdatnianie i dostarczanie wody. Ostatnie dwie wymienione branże zwracają uwagę nie tyle z powodu korzyści wynikających z otwarcia gospodarki, ponieważ nie są to sektory, w których otwarcie gospodarki daje możliwości ekspansji na rynkach zagranicznych. Mamy tu do czynienia z poprawą rentowności (o 109\% w przypadku poboru, uzdatniania i dostarczania wody oraz o 113\% w branży „wytwarzanie i zaopatrywanie w energię elektryczną"), osiągniętej dzięki zmniejszeniu w latach 2004-2010 liczby przedsiębiorstw działających w tych branżach (zob. tabela 3).

Tabela 6. Efekt selekcji w Polsce w latach 2004-2010

\begin{tabular}{|c|c|c|c|}
\hline BRANŻA & liczba firm & rentowność & $\begin{array}{c}\text { EFEKT } \\
\text { SELEKCJI }\end{array}$ \\
\hline Górnictwo i wydobywanie & - & - & \\
\hline Produkcja artykułów spożywczych i napojów & - & ++ & $\mathbf{x}$ \\
\hline Produkcja wyrobów tytoniowych & ++ & ++ & \\
\hline Produkcja wyrobów tekstylnych & - & - & \\
\hline Produkcja odzieży & - & - & \\
\hline Produkcja skór i wyrobów skórzanych & - & ++ & $\mathbf{X}$ \\
\hline Produkcja wyrobów z drewna, korka, słomy i wikliny & - & - & \\
\hline Produkcja papieru i wyrobów z papieru & ++ & - & \\
\hline Poligrafia i reprodukcja zapisanych nośników informacji & - & - & \\
\hline Produkcja koksu i produktów rafinacji ropy naftowej & ++ & - & \\
\hline Produkcja chemikaliów i wyrobów chemicznych & - & - & \\
\hline Produkcja wyrobów z gumy i tworzyw sztucznych & ++ & - & \\
\hline Produkcja wyrobów z poz. mineralnych surowców niemetalicznych & - & - & \\
\hline Produkcja metali & + & - & \\
\hline Produkcja wyrobów z metali & ++ & - & \\
\hline Produkcja komputerów, wyrobów elektronicznych i optycznych & ++ & - & \\
\hline Produkcja urządzeń elektrycznych & - & - & \\
\hline Produkcja maszyn i urządzeń & - & ++ & $\mathbf{X}$ \\
\hline Produkcja pojazdów samochodowych & ++ & & \\
\hline Produkcja pozostałego sprzętu transportowego & - & ++ & $\mathbf{X}$ \\
\hline Produkcja mebli & - & - & \\
\hline Wytwarzanie i zaopatrywanie w energię elektryczną gaz, parę & - & ++ & $\mathbf{x}$ \\
\hline Pobór, uzdatnianie i dostarczanie wody & - & ++ & $\mathbf{x}$ \\
\hline Gospodarka odpadami; odzysk surowców & ++ & ++ & \\
\hline
\end{tabular}

Źródło: opracowanie własne. 
Podsumowując, możemy stwierdzić, iż otwarcie rynków i zwiększenie wymiany handlowej z krajami UE po 2004 r. przyczyniło się do istotnego zmniejszenia liczby firm działających we wskazanych branżach. Jednocześnie nastąpiła widoczna poprawa ich rentowności, co należy uznać za pozytywny efekt gospodarki otwartej.

\section{ZAKOŃCZENIE}

$\mathrm{Na}$ podstawie modelu Krugmana dotyczącego efektu skali i selekcji po wejściu Polski do Unii Europejskiej wyznaczono branże, w których wyraźnie wzrosły przychody ze sprzedaży (krajowej i zagranicznej) oraz uległa zmianie liczba producentów.

Na podstawie danych o działalności polskich przedsiębiorstw dokonano oceny wpływu otwarcia gospodarki na funkcjonowanie przedsiębiorstw produkcyjnych. Okazało się, że efekt skali dotyczył zupełnie innych branż niż efekt selekcji. Zwiększenie przychodów ze sprzedaży osiągnięte dzięki występującym rosnącym korzyściom skali przy jednoczesnym wzroście liczby producentów zaobserwowano w następujących branżach: produkcji papieru, produkcji koksu i produktów rafinacji ropy naftowej, produkcji wyrobów z gumy i tworzyw sztucznych, produkcji wyrobów z metali, produkcji komputerów, wyrobów elektronicznych i optycznych, a także produkcji pojazdów samochodowych. Dwie ostatnie z wymienionych branż to przykłady rynków konkurencji monopolistycznej, na których występują zróżnicowane dobra. Zgodnie z cechami modelu rynku konkurencji monopolistycznej przedstawionymi w części pierwszej niniejszego opracowania, cecha ta sprzyja odnoszeniu korzyści przez producentów w gospodarce otwartej.

Efekt selekcji natomiast zaobserwowano w produkcji artykułów spożywczych i napojów, produkcji skór i wyrobów skórzanych, produkcji maszyn i urządzeń, produkcji pozostałego sprzętu transportowego, wytwarzaniu i zaopatrywaniu $\mathrm{w}$ energię elektryczną (...) oraz poborze i uzdatnianiu wody. Pomijając, zgodnie z wcześniejszą charakterystyką, dwie ostatnie branże, w których wzrost rentowności osiągnięto nie dzięki otwarciu gospodarki, ale spadkowi liczby firm działających w tych branżach, należy stwierdzić, że wymienione branże produkcyjne nie zdołały oprzeć się konkurencji producentów zagranicznych, którzy pojawili się na polskim rynku po 2004 r. Warto jednak przy tym zauważyć, że w branży spożywczej i tytoniowej poprawa rentowności osiągnęła 100\%. Zatem otwarcie polskiego rynku także i w tych branżach przyniosło pozytywne efekty. 


\title{
BIBLIOGRAFIA
}

Dixit A. K., Stiglitz J. E., Monopolistic Competition and Optimum Product Diversity, „American Economic Review”1977, no. 67 (3), s. 297-308.

Feenstra R., Advanced International Trade: Theory and Evidence, Princeton University Press 2003.

Handel zagraniczny (styczeń-grudzień), GUS, za lata 2004-2010.

Head K., Ries J., Can Small-Country Manufacturing Survive Trade Liberalization? Evidence from the Canada-U.S. Free Trade Agreement, „Perspectives on North American Free Research Publication” 1999, no. 1.

Head K., Ries J., Increasing Returns versus National Product Differentiation as an Explanation for the Pattern of U.S.-Canada Trade, „American Economic Review” 2001, no. 91 (4), s. 858-876.

Krugman P., Scale economies, product differentiation, and the pattern of trade, „American Economic Review” 1980, no. 70 (5), s. 950-981.

„Nakłady i wyniki przemysłu”, GUS, za lata 2004-2010.

„Rocznik statystyczny przemysłu”, GUS, za lata 2004-2010.

\section{STRESZCZENIE}

W ostatnich siedmiu latach $\mathrm{w}$ polskiej gospodarce nastąpiły bardzo istotne zmiany. Otwarcie rynku to przede wszystkim korzyści wynikające ze wzrostu produkcji i rozszerzenia rynku zbytu. Jednocześnie z rynku wypadły firmy, które nie zdołały oprzeć się konkurencji. W wyniku otwarcia gospodarki mamy do czynienia z dwoma przeciwnymi efektami - efektem skali, kiedy firmy zwiększają produkcję, oraz efektem selekcji, gdy firmy pod presją konkurencji zmuszone są wyjść z branży.

Badanie efektu skali pozwoliło określić branże, które w badanym okresie odnotowały korzyści płynące $z$ otwarcia rynków. Wzrosły w tych branżach przychody ze sprzedaży, przychody ze sprzedaży zagranicznej oraz liczba przedsiębiorstw. Z kolei na podstawie danych o spadku liczby przedsiębiorstw w latach 2004-2010 oraz poprawie wskaźnika rentowności wybrano branże, w których wystąpił efekt selekcji.

$\mathrm{Na}$ podstawie efektu skali i selekcji dokonano oceny wpływu otwarcia gospodarki na funkcjonowanie przedsiębiorstw produkcyjnych.

\section{SCALE EFFECT AND SELECTION EFFECT AFTER POLAND'S ACCESSION TO THE EUROPEAN UNION}

\author{
SUMMARY
}

The last seven years have brought about significant changes in the Polish economy. Market openness means above all the benefits of higher production, and market expansion. This implies, however, with a decrease in the number of companies that fail to deal with the 
incoming of foreign competition. As a result of opening the market, we are dealing with two opposing effects - the scale effect, as firms expand their outputs, and the selection effect, as some firms are forced to exit due to the pressure of foreign competition.

The study identifies a scale effect in these industries, which increased revenue, export sales, and the number of firms.

In turn, the selection effect was identified on the basis of the decrease in the number of firms in 2004-2010 and improvement of the profitability ratio.

The evaluation of these two effects reflects the impact of opening the economy to the functioning of manufacturing companies. 